\title{
Omeprazole and ranitidine in the prevention of relapse in patients with duodenal ulcer disease
}

K Lauritsen $\mathrm{MD}^{1}, \mathrm{~K}$ Rutgersson $\mathrm{MD}^{2}$, E Bolling $\mathrm{MD}^{2}$, G Brunner $\mathrm{MD}^{3}, \mathrm{~S}^{2}$ Eriksson $\mathrm{MD}^{3}$, JP Galmiche $\mathrm{MD}^{4}$, A Walan $\mathrm{MD}^{2}$,

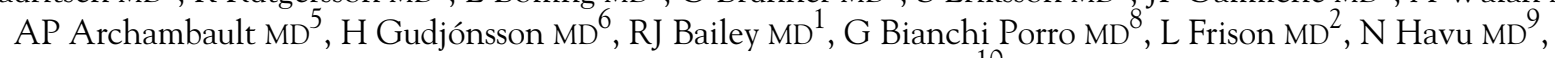
ABR Thompson MD FRCPC ${ }^{10}$

K Lauritsen, K Rutgersson, E Bolling, et al. Omeprazole and ranitidine in the prevention of relapse in patients with duodenal ulcer disease. Can J Gastroenterol 1999;13(10):806-813.

BACKGROUND: Although the eradication of Helicobacter pylori is of primary importance when initiating treatment, it is also important to have a strategy for patients who are $\mathrm{H}$ pylori-negative, fail to demonstrate eradication or have a tendency to become re-infected or relapse.

PATIENTS AND METHODS: In a double-blind, parallel-group clinical trial of 928 patients (from 70 centres in 16 countries) with duodenal ulcers who after a short term study had relief of symptoms and healed ulcers proved endoscopically, 308 were randomly assigned to receive omeprazole $10 \mathrm{mg}$ in the morning, 308 to receive omeprazole $20 \mathrm{mg}$ in the morning and 312 to receive ranitidine $150 \mathrm{mg}$ at bedtime for up to 12 months. Symptoms were assessed every three months and endoscopy repeated at three, six and 12 months, or more often if indicated by recurrence of symptoms. The safety screening included basal serum gastrin concentrations and gastric mucosal histopathology.

RESULTS: The remission rates up to 12 months were $87 \%$ for the omeprazole $20 \mathrm{mg}$ group, $71 \%$ for the omeprazole $10 \mathrm{mg}$ group and $63 \%$ for the ranitidine group. Omeprazole $20 \mathrm{mg}$ differed significantly from both omeprazole $10 \mathrm{mg}(\mathrm{P}=0.0001,95 \% \mathrm{CI} 9$ to 23 ) and ranitidine ( $\mathrm{P}=0.0001,95 \% \mathrm{CI} 17$ to 31$)$. There was no statistically significant difference between omeprazole $10 \mathrm{mg}$ and ranitidine over the 12 -month period, but the $95 \%$ confidence interval allowed differences between $0 \%$ and $16 \%$ in favour of omeprazole at 12 months. A Cox regression analysis revealed that longer treatment courses to heal, smoking, a long ulcer history and young age negatively contributed to the odds of staying in remission. The treatments were well tolerated. There was a slight increase in basal serum gastrin concentrations, reflecting the different degrees of acid inhibition induced by the three treatments. No dysplastic or neoplastic lesions were found in any biopsies.

CONCLUSIONS: More duodenal ulcer patients are maintained in remission with omeprazole $20 \mathrm{mg}$ daily than with omeprazole $10 \mathrm{mg}$ daily or with ranitidine $150 \mathrm{mg}$ at bedtime.

Key Words: Clinical trials; Duodenal ulcer; Gastrin; Maintenance treatment; Omeprazole; Peptic ulcer; Prophylaxis; Ranitidine; Relapse prevention

\section{Oméprazole et ranitidine dans la prévention de l'ulcère duodénal}

HISTORIQUE : Bien que l'éradication d'Helicobacter pylori soit de la première importance lorsqu'on amorce le traitement, il est également impérieux de se doter d'une stratégie pour les patients $H$. pylori-négatifs, ceux chez qui l'éradication échoue ou qui ont tendance à rechuter ou se réinfecter.

PATIENTS ET MÉTHODES : Dans le cadre d'un essai clinique à double insu avec groupe parallèle sur 928 patients (provenant de 70 centres répartis entre 16 pays) atteints d'ulcères duodénaux qui, après une courte étude ont éprouvé un soulagement de leurs symptômes et une cicatrisation de leurs ulcères, endoscopie à l'appui, 308 ont été assignés aléatoirement à de l'oméprazole $10 \mathrm{mg}$ le matin, 308 à de l'oméprazole $20 \mathrm{mg}$ le matin et

voir page suivante

${ }^{1}$ Odense University Hospital, Denmark; ${ }^{2}$ Astra Hässle AB, Mölndal, Sweden; ${ }^{3}$ Medizinische Hochschule Hannover, Germany; ${ }^{4}$ Hôpital Guillaume et René Laënnec, Nantes, France; ${ }^{5}$ University Hospital, Montreal, Canada; ${ }^{6}$ Landspítalinn, Reykjavík, Iceland; ${ }^{7}$ Royal Alexandra Hospital, Edmonton, Alberta; ${ }^{8}$ Ospedale "L Sacco", Milano, Italy; ${ }^{9}$ AB Astra, Södertälje, Sweden; ${ }^{10}$ On behalf of an International Multicentre Study Group (participating investigators from 70 centres in 16 countries are listed in the acknowledgements), University of Alberta, Edmonton, Alberta

Correspondence: Dr Alan BR Thomson, Department of Medicine, Division of Gastroenterology, University of Alberta, Edmonton, Alberta T6G 2C2. Telephone 780-407-6490, fax 780-407-7964, e-mail alan.thomson@ualberta.ca 
312 à de la ranitidine, $150 \mathrm{mg}$ au coucher, pendant une période allant jusqu'à 12 mois. Les symptômes ont été évalués tous les trois mois et l'endoscopie a été reprise à 3, 6 et 12 mois ou plus souvent en cas de récurrence des symptômes. La vérification de l'innocuité se faisait, entre autre, par un dosage des concentrations de gastrine sérique basale et par des tests histopathologiques de la muqueuse gastrique.

RÉSULTATS : Les taux de rémission jusqu’à 12 mois ont été de $87 \%$ dans le groupe sous oméprazole $20 \mathrm{mg}$, de $71 \%$ dans le groupe sous oméprazole $10 \mathrm{mg}$ et de $63 \%$ dans le groupe ranitidine. L'oméprazole $20 \mathrm{mg}$ donne des résultats significativement différents de l'oméprazole $10 \mathrm{mg}(p=0,001$, IC $95 \% 9$ à 23) et la ranitidine ( $p=0,001$, IC $95 \% 17$ à 31). On n'a noté aucune différence statistiquement significative entre l'oméprazole $10 \mathrm{mg}$ et la ranitidine au cours de la période de 12 mois et l'intervalle de confiance de $95 \%$ a permis d'établir des différences de 0 à $16 \%$ en faveur de l'oméprazole à 12 mois. L'analyse de régression de Cox a révélé que la prolongation des traitements pour l'obtention de la guérison, les antécédents d'ulcères de longue date et le jeune âge contribuaient de façon négative à la probabilité de rester en rémission. Les traitements ont été bien tolérés. On a noté une légère augmentation des taux de gastrine sérique basale indicateurs des degrés différents d'inhibition acide provoquée par les trois traitements. Aucune atteinte dysplasique ou néoplasique n'a été observée dans l'une ou l'autre des biopsies.

CONCLUSION : Un plus grand nombre de patients atteints d'ulcères duodénaux ont été maintenus en rémission avec l'oméprazole $20 \mathrm{mg}$, 1 f.p.j. qu'avec l'oméprazole $10 \mathrm{mg}, 1$ f.p.j. ou avec la ranitidine $150 \mathrm{mg}$ au coucher.
$\mathrm{O}$ meprazole, a substituted benzimidazole that is a potent inhibitor of the proton pump of the parietal cell, reduces intragastric acidity more effectively than $\mathrm{H}_{2}$ receptor antagonists (1). Numerous studies in patients with duodenal ulcer disease have shown that administration of omeprazole 20 to $40 \mathrm{mg}$ daily accelerates healing and relief of pain compared with cimetidine or ranitidine (2). This benefit of omeprazole in the short term treatment of duodenal ulcers was obtained without major clinical or biochemical side effects, but when the present study was planned, further research was needed into longer term use of the drug (2).

After healing, approximately $70 \%$ to $100 \%$ of patients relapse during the first year without intervention. Several agents have been shown to reduce the incidence of endoscopic relapse (3), and a few, including ranitidine, have been widely used as 'maintenance treatment' for the prevention of ulcer relapse. Nevertheless, even ranitidine $150 \mathrm{mg}$ taken at bedtime fails to prevent recurrence in every third (4) or fourth (5) patient within one year. These figures show that there is room for improvement of the drug treatment of duodenal ulcer disease. Omeprazole $10 \mathrm{mg}$ daily or $20 \mathrm{mg}$ three days a week is effective and safe in keeping a large proportion of patients in remission $(6,7)$. Some patients, however, might benefit from a more profound acid inhibition provided by the standard healing dose of omeprazole $20 \mathrm{mg}$ daily (8). A recent six-month trial of 472 duodenal ulcer patients demonstrated estimated remission rates of $90 \%$ for omeprazole $20 \mathrm{mg}$ every morning and $82 \%$ for ranitidine $150 \mathrm{mg}$ at bedtime (9). While it is accepted that eradication of an associated Helicobacter pylori infection alters the natural history of duodenal ulcer disease, some patients with a duodenal ulcer are negative for this infection and may, therefore, require maintenance therapy with acid-lowering medications. Furthermore, there are instances where treatment of $H$ pylori fails (10), and where it is appropriate to have a maintenance strategy that allows ulcer patients the optimal opportunity to remain in remission from their disease.

For these reasons we compared the effect of maintenance treatment with omeprazole (10 or $20 \mathrm{mg}$ once daily) with that of the recommended maintenance dose of ranitidine (150 $\mathrm{mg}$ at bedtime) on the time to ulcer relapse during a 12 -month period. The results show that more duodenal ulcer patients are maintained in remission with omeprazole $20 \mathrm{mg}$ daily than with omeprazole $10 \mathrm{mg}$ daily or with ranitidine $150 \mathrm{mg}$ at bedtime. The $20 \mathrm{mg}$ dose of omeprazole is, therefore, recommended for ulcer patients who need continued maintenance treatment.

\section{PATIENTS AND METHODS}

Eligibility criteria: Patients aged 18 to 80 years who had at least one endoscopically proven duodenal ulcer with a greater axis of at least $5 \mathrm{~mm}$ and who had been included in a study on duodenal ulcer healing (omeprazole for two to 16 weeks) were considered for the trial. Criteria for recruitment were that ulcer healing (ie, complete re-epithelialization of the ulcer site) and symptom relief had been obtained. The short term protocol (11) was a double-blind comparison of omeprazole $20 \mathrm{mg}$ and $40 \mathrm{mg}$ in the morning for up to eight weeks for ulcer healing (patients stopped treatment if ulcer healing and symptom relief had occurred at two or four weeks; patients with unhealed ulcers or more than mild symptoms after eight weeks received omeprazole $40 \mathrm{mg}$ on an open basis for up to another eight weeks). Exclusion criteria were lack of informed consent; planned or current pregnancy or lactation; ulcer bleeding or pyloric stenosis necessitating surgical intervention; concomitant gastric or prepyloric ulcer, or erosive or ulcerative esophagitis; previous gastric surgery except for simple closure; and concomitant treatment or disease (such as liver or renal failure) likely to complicate evaluation of the drugs. Each patient gave informed consent, and the study protocol was approved by the health authorities of the country of each participating centre and by the appropriate ethics committees.

Study design: Before entry, a clinical history was taken, symptoms were assessed (the intensity of pain during the day and night being scored as none, mild [occasional but not interfering with normal activities], moderate [occasional interference with normal activities] and severe [constant interference with normal activities]), and the patient underwent a physical examination and laboratory screening (leukocyte and platelet counts; hemoglobin, serum creatinine and total bilirubin concentrations; alkaline phosphatase and alanine and/or aspartate aminotransferase activities). Patients were randomly assigned (by a com- 
puter-generated randomization list stratified for centre in blocks of three) to treatment with omeprazole (Astra Hässle $\mathrm{AB}$, Sweden), either one $10 \mathrm{mg}$ capsule in the morning or one $20 \mathrm{mg}$ capsule in the morning, or to ranitidine (Glaxo, United Kingdom) one $150 \mathrm{mg}$ tablet at bedtime. Placebo capsules/tablets were prepared so that all patients received both sizes of capsules in the morning and one tablet at bedtime. Patients were encouraged not to take any antacids during the study. All other antiulcer treatment was abandoned.

Patients were assessed clinically after three, six, nine and 12 months, or more often if indicated by recurrence of symptoms, for clinical assessment, repeat laboratory tests (omitted at three and nine months) and endoscopy (omitted at nine months in patients who were symptom-free). The main end point was endoscopically proven recurrence of an ulcer with or without symptoms. Patients completed the study after 12 months or earlier if recurrence was seen. Returned study drugs were counted at each visit, and patients later found to have taken less than $75 \%$ of the prescribed amount of study medication per study period were regarded as noncompliant in the analysis.

At the pre-entry visit in the healing study (before medication with omeprazole), at six and 12 months or in the event of recurrence or discontinuation, four to six mucosal biopsy specimens were taken from the oxyntic mucosa along the greater curvature. The specimens were immediately fixed in $10 \%$ formalin or in Bouin's fixative. The specimens were examined histochemically, primarily by silver staining (Sevier-Munger), to determine qualitatively the density of endocrine cells and also by hematoxylin eosin staining to assess the general pathology. Unfortunately, the $H$ pylori status of the patients was not available. All biopsy specimens were examined by the same pathologist on 'blinded' samples. The endocrine cells were classified according to Solcia et al (12). At the same visits, blood samples for the measurement of serum gastrin concentrations in the fasting state were collected in glass tubes and centrifuged, and serum was transferred to plastic tubes and stored at $-20^{\circ} \mathrm{C}$ until analysis. The gastrin concentrations were determined by a radioimmunoassay according to the method of Rehfeld et al (13).

Statistical considerations: In planning the trial, the relapse rate in the ranitidine group was estimated to be $20 \%$, and reducing this rate by at least $10 \%$ (to $10 \%$ ) was considered to be clinically meaningful. It was calculated (14) that roughly 900 patients (300 in each of three treatment groups) would be needed to give a test power of at least $80 \%$ to detect this difference in relapse rates with a two-sided test and an overall $5 \%$ significance level (allowing for a 10\% dropout rate and using the Bonferroni method for adjustment of the significance level for three pairwise comparisons).

A life-table analysis of time in remission was performed according to the actuarial life-table method (15), and a log rank test was used for comparison of the treatment groups. The data were subjected to both a 'per protocol' (PP) analysis, ie, comprising only patients who completed an assessment period without major protocol deviations, and an 'all patients treated' (APT) analysis, ie, comprising all patients who took at least one dose of study drug (16). Patients lost to follow-up, or those discontinued due to adverse events or for other reasons were considered as having been under risk until the visit at which their state was last known (ie, censored observation time). In the PP approach, a patient was considered to have had a relapse in the event of an ulcer with or without symptoms. In the APT approach, the definition used was ulcer and/or symptomatic relapse. The possible influence of some prognostic factors on the time in remission was considered using a Cox regression analysis (17). The factors considered in the model were study drug, time to healing, smoking habits (no smoking, one to 10 cigarettes/day, 11 to 20 cigarettes/day or more than 20 cigarettes/day), duration of ulcer history, age, sex, centre, ulcer size before entry into the study and use of nonsteroidal anti-inflammatory drugs (NSAIDs). The SAS procedure PHREG was used in these calculations (18).

Laboratory values were compared in terms of the number of patients with decreased, unchanged and increased values. Within treatment groups, the hypothesis that increased and decreased values were equally probable was tested using the sign test. Between-group comparisons were made using a $\chi^{2}$ test of homogeneity. A cross-table showing the number of patients with a value below, within or above the normal range at baseline versus the same classification at last visit was provided for each laboratory variable. Serum gastrin values, which were analyzed in a standardized manner in one laboratory, were compared in terms of mean baseline values and mean change from baseline to end of treatment. Confidence intervals were calculated for the mean change within treatment groups. Changes between treatment groups were compared using unpaired $t$ tests. All tests were two-sided, with a significance level of $5 \%$.

\section{RESULTS}

Description and comparison of treatment groups: A total of 928 patients from 70 centres in 16 countries were entered into the study. The treatment groups were well matched for selected patient characteristics (Table 1). Thirty-seven patients discontinued treatment (Table 2) because of various events, which, in the context of the protocol, were classified as adverse events: 14 patients receiving $10 \mathrm{mg}$ omeprazole (burning sensations in extremities, thrombocytopenia, bladder carcinoma, myocardial infarction, rash, angina pectoris, acute pancreatitis, abnormal taste, diarrhea, death due to subarachnoid hemorrhage, suicide, sudden death [two cases], and death due to cirrhosis and septicemia), 16 patients receiving $20 \mathrm{mg}$ omeprazole (constipation, chest pain, arteriosclerosis of both legs, hypertension, ulcerative colitis, bile duct carcinoma, pruritus, backache, abdominal pain, psychosis, influenza, nausea, dizziness, depression, death due to stroke, death due to myocardial infarction) and seven patients receiving ranitidine (angina pectoris, nausea, scotoma, colonic cancer, gastric cancer, abdominal pain and death due to myocardial infarction). Fifty-six patients were lost to follow-up ( 29 before the three months' visit), and 20 patients 
TABLE 1

Characteristics of patients with duodenal ulcers who had relief of symptoms and healed ulcers proven by endoscopy

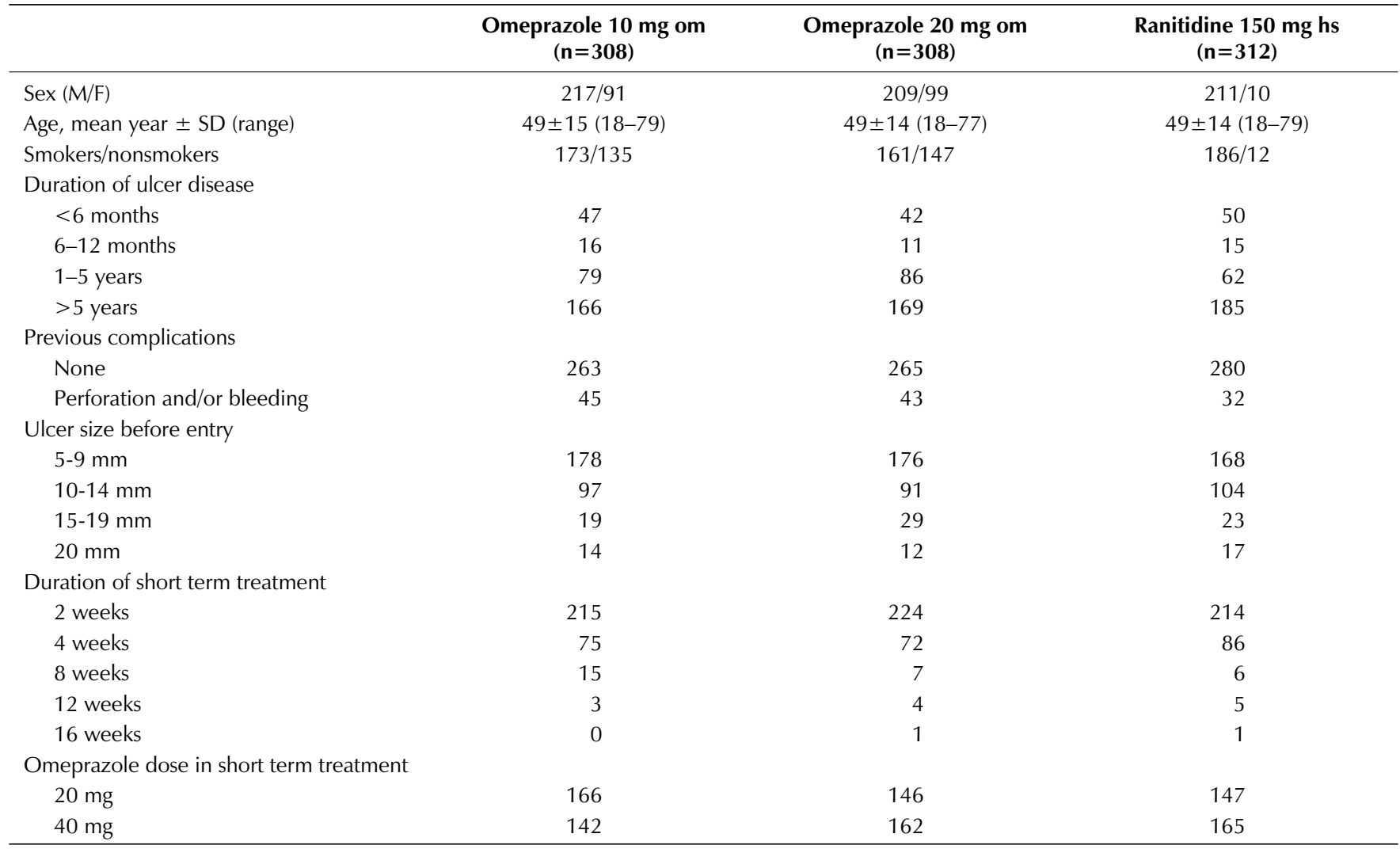

hs At bedtime; om In the morning

TABLE 2

Patient outcome by treatment group

\begin{tabular}{|c|c|c|c|}
\hline & $\begin{array}{l}\text { Omeprazole } \\
10 \text { mg om } \\
(n=308)\end{array}$ & $\begin{array}{l}\text { Omeprazole } \\
20 \text { mg om } \\
(n=308)\end{array}$ & $\begin{array}{c}\text { Ranitidine } \\
150 \mathrm{mg} \text { hs } \\
(\mathrm{n}=312)\end{array}$ \\
\hline In remission & 183 & 229 & 175 \\
\hline Relapsed & 82 & 37 & 109 \\
\hline Symptomatic ulcer & 62 & 22 & 60 \\
\hline $\begin{array}{l}\text { Asymptomatic } \\
\text { ulcer }\end{array}$ & 17 & 12 & 43 \\
\hline Symptoms only* & 3 & 3 & 6 \\
\hline $\begin{array}{l}\text { Discontinued } \\
\text { because of } \\
\text { adverse event }\end{array}$ & 14 & 16 & 7 \\
\hline Lost to follow-up & 23 & 19 & 14 \\
\hline $\begin{array}{r}\text { Discontinued for } \\
\text { other reasons }\end{array}$ & 6 & 7 & 7 \\
\hline
\end{tabular}

*Includes patients in whom no endoscopy was performed because they refused to participate, were pregnant or emigrated. hs At bedtime; om In the morning

discontinued for other reasons (Table 2). In the PP survival analysis, a further 14 patients in each omeprazole group and 15 receiving ranitidine had censored observation time due to noncompliance with the study medication. Five on omeprazole $10 \mathrm{mg}$, six on omeprazole $20 \mathrm{mg}$ and eight on

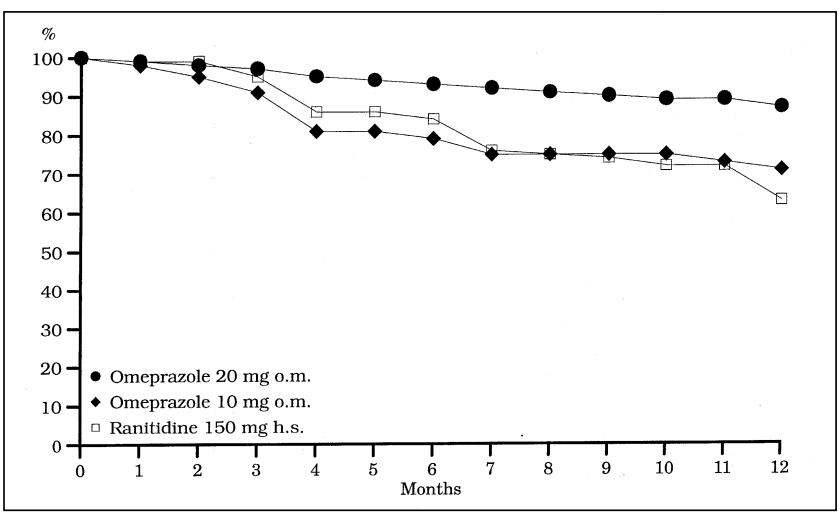

Figure 1) Proportion of patients in remission in three treatment groups. Data are analyzed by an 'all patients treated' approach; an analysis by a 'per protocol' approach resulted in almost identical curves (not shown). h.s. At bedtime; o.m. In the morning

ranitidine had censored observation time due to symptomatic relapses (not endoscopically verified) or for other reasons such as a too early end-of-study visit. Eighteen patients (6\%) receiving $10 \mathrm{mg}$ omeprazole, 14 patients (5\%) receiving $20 \mathrm{mg}$ omeprazole and 22 patients (7\%) receiving ranitidine used antacids on one or more occasions during the study. Although antacid use was discouraged, these patients were not excluded from analysis as a result of its use. 
TABLE 3

The number of relapses and estimated remission rates at 12 months for prognostic factors tabulated by treatment group

\begin{tabular}{|c|c|c|c|}
\hline & $\begin{array}{c}\text { Omeprazole } \\
10 \mathrm{mg} \mathrm{om} \text {, relapses (remission*) }\end{array}$ & $\begin{array}{c}\text { Omeprazole } \\
20 \mathrm{mg} \text { om }+150 \mathrm{mg} \text { hs } \\
\text { relapses (remission*) }\end{array}$ & $\begin{array}{c}\text { Ranitidine } \\
\text { relapses (remission*) }\end{array}$ \\
\hline 2 weeks & $48 / 215(74 \%)$ & $15 / 224(92 \%)$ & $64 / 214(66 \%)$ \\
\hline 4 weeks & $22 / 75(67 \%)$ & $12 / 72(81 \%)$ & $26 / 86(66 \%)$ \\
\hline 8-16 weeks & $5 / 18(68 \%)$ & $5 / 12(43 \%)$ & $6 / 12(44 \%)$ \\
\hline None & $27 / 135(78 \%)$ & 8/147 (94\%) & $29 / 126(74 \%)$ \\
\hline One to 10 cigarettes/day & $10 / 37(70 \%)$ & $6 / 48(85 \%)$ & $15 / 51(64 \%)$ \\
\hline 11 to 20 cigarettes/day & $26 / 93(65 \%)$ & $12 / 74(81 \%)$ & $38 / 88$ (53\%) \\
\hline$>20$ cigarettes/day & $12 / 43(66 \%)$ & $6 / 39(82 \%)$ & $14 / 47(63 \%)$ \\
\hline \multicolumn{4}{|l|}{ Duration of ulcer disease } \\
\hline 19 to 49 years & $47 / 165(66 \%)$ & 19/147 (85\%) & $51 / 162(64 \%)$ \\
\hline 50 to 64 years & $22 / 86(72 \%)$ & $12 / 116(89 \%)$ & 28/99 (69\%) \\
\hline 65 to 90 years & $6 / 57(88 \%)$ & $1 / 45(98 \%)$ & $17 / 51(60 \%)$ \\
\hline
\end{tabular}

*Actuarial lifetable analysis, 'per-protocol' cohort. hs At bedtime; om In the morning

Relapse of ulcer disease: The outcomes in the three treatment groups with regard to the number of patients with symptomatic ulcers, with silent ulcers detected at scheduled endoscopies, or number of patients who discontinued for ulcer symptoms of moderate or severe intensity (with or without endoscopy) are summarized in Table 2. The curves for the proportions of patients in remission estimated in the actuarial lifetable analysis (Figure 1) showed that more patients were maintained in remission with omeprazole than with ranitidine (APT analysis). The remission rates up to 12 months were $87 \%$ for the omeprazole $20 \mathrm{mg}$ group, $71 \%$ for the omeprazole $10 \mathrm{mg}$ group and $63 \%$ for the ranitidine group. Comparison of the remission curves (log rank test) indicated that omeprazole $20 \mathrm{mg}$ differed significantly from both omeprazole $10 \mathrm{mg} \quad(\mathrm{P}=0.0001)$ and ranitidine $(\mathrm{P}=0.0001)$. There was no significant difference $(\mathrm{P}=0.18)$ between omeprazole $10 \mathrm{mg}$ and ranitidine. The $95 \%$ confidence interval for the difference in true relapse rates at 12 months allowed, however, for any difference between 0\% and $16 \%$ in favour of omeprazole over ranitidine.

The time in remission as analyzed by a PP approach resulted in almost identical curves, with remission rates up to 12 months of $88 \%$ (omeprazole $20 \mathrm{mg}$ group), $72 \%$ (omeprazole $10 \mathrm{mg}$ ) and 65\% (ranitidine group). Over the year, recurrences with symptoms were observed in $7 \%$ of the total number of patients in the omeprazole $20 \mathrm{mg}$ group, $20 \%$ in the omeprazole $10 \mathrm{mg}$ group and $19 \%$ in the ranitidine group. Asymptomatic recurrences were observed in $4 \%, 6 \%$ and $14 \%$ in the omeprazole $20 \mathrm{mg}$, omeprazole $10 \mathrm{mg}$ and ranitidine group, respectively.

The Cox regression analysis of possible prognostic factors revealed that longer treatment courses to heal $(\mathrm{P}=0.0001)$, smoking $(\mathrm{P}=0.0001)$, a long ulcer history $(\mathrm{P}=0.001)$ and young age $(\mathrm{P}=0.009)$ negatively contributed to the odds of staying in remission (Table 3 ). In particular, young smokers with an ulcer history longer than one year appeared to have had a 'high risk' of relapse. Thirty-six patients were treated with NSAIDs during the study (16 on omeprazole $10 \mathrm{mg}$, and 10 in each of the other two treatment groups). All these patients remained in remission during the study period. In patients who were treated with NSAIDs intermittently - 32 on omeprazole $10 \mathrm{mg}, 19$ on omeprazole $20 \mathrm{mg}$ and 23 on ranitidine - four, three and eight patients had a relapse, respectively.

Adverse events and laboratory findings: The protocol defined an adverse event as any unfavourable, unintended event or symptom associated with administration of the study drugs, whether or not considered causally related to these drugs, reported by the patient spontaneously or in response to a standard question, or observed by the investigator. The frequencies of adverse events were similar in the three treatment groups when duration of treatment, ie, adverse event assessment time, was accounted for (Table 4). The types of events were essentially the same, the most commonly reported being headache and gastrointestinal disturbances (Table 5). Most of the reported events were minor, transient or explainable on the basis of underlying disease or concurrent conditions. Thirty-seven patients (Table 2) discontinued treatment due to adverse events as described above. None of the events resulting in death was considered to be causally related to either omeprazole or ranitidine.

No clinically important changes that could be attributed 
TABLE 4

Treatment time and number of adverse events by treatment group

\begin{tabular}{|c|c|c|c|}
\hline & $\begin{array}{c}\text { Omeprazole } \\
10 \mathrm{mg} \text { om } \\
(\mathrm{n}=308)\end{array}$ & $\begin{array}{c}\text { Omeprazole } \\
20 \text { mg om } \\
(n=308)\end{array}$ & $\begin{array}{c}\text { Ranitidine } \\
150 \mathrm{mg} \text { hs } \\
(\mathrm{n}=312)\end{array}$ \\
\hline $\begin{array}{l}\text { Average treatment time } \\
\text { (days) }\end{array}$ & 265 & 306 & 281 \\
\hline $\begin{array}{l}\text { Treatment time } \\
\text { (patient-years) }\end{array}$ & 223.6 & 258.2 & 240.2 \\
\hline $\begin{array}{l}\text { Number of adverse events } \\
\text { recorded }\end{array}$ & 204 & 236 & 206 \\
\hline $\begin{array}{l}\text { Number of adverse events } \\
\text { per patient-year }\end{array}$ & 0.91 & 0.91 & 0.86 \\
\hline
\end{tabular}

hs At bedtime; om In the morning

to treatment were observed in the laboratory values. There was a slight increase in fasting serum gastrin concentrations (but rarely to levels above the upper reference limit of $100 \mathrm{pmol} / \mathrm{L}$ ), reflecting the different degrees of acid inhibition induced by the three treatments (8) (Figure 2).

Gastric biopsy specimens were obtained from 814 patients both before treatment and at the last visit. The majority had some degree of gastritis in the body of the stomach (classified as slight, moderate, subatrophic or atrophic) before the start of ulcer treatment $-59 \%, 66 \%$ and $66 \%$ of patients in the omeprazole $10 \mathrm{mg}$, omeprazole $20 \mathrm{mg}$ and ranitidine groups, respectively. At the six-month visit, the corresponding figures were $79 \%, 88 \%$ and $77 \%$ of the patients, respectively. The increase in the frequency of gastritis was predominantly from normal mucosa to slight or moderate gastritis in all treatment groups. There was no further increase in the degree of gastritis during the last six months of treatment. Subatrophic or atrophic gastritis was more commonly seen in older patients. Before entry, focal (linear and micronodular) hyperplasia (12) was observed in seven, two and four patients in the omeprazole $10 \mathrm{mg}$, omeprazole $20 \mathrm{mg}$ and ranitidine groups, respectively. Of these, micronudular hyperplasia was observed in eight patients. This finding was not observed in any of these at the end of treatment. Focal hyperplasia at the end of treatment was slightly more prevalent in the omeprazole groups (16 and 20 patients in the $10 \mathrm{mg}$ and $20 \mathrm{mg}$ groups, respectively) than in the ranitidine group (five patients). Independent of study drug, the frequency of focal hyperplasia was related to older age, subatrophic or atrophic gastritis and to elevated serum gastrin concentrations in the fasting state (higher than $50 \mathrm{pmol} / \mathrm{L})$. No dysplastic or neoplastic lesions were found in any biopsy specimen before or during treatment.

\section{DISCUSSION}

The present data show that omeprazole $20 \mathrm{mg}$ in the morning is significantly superior to both omeprazole $10 \mathrm{mg}$ in the morning and ranitidine $150 \mathrm{mg}$ at bedtime in keeping patients with duodenal ulcer disease in remission. More patients tended to stay in remission in the omeprazole $10 \mathrm{mg}$ group than in the ranitidine group, although this difference
TABLE 5

The most commonly reported adverse events (higher than $2 \%)$ by treatment group

\begin{tabular}{|c|c|c|c|}
\hline & $\begin{array}{l}\text { Omeprazole } \\
10 \text { mg om } \\
(n=308)\end{array}$ & $\begin{array}{c}\text { Omeprazole } \\
20 \text { mg om } \\
(n=308)\end{array}$ & $\begin{array}{c}\text { Ranitidine } \\
150 \mathrm{mg} \text { hs } \\
(\mathrm{n}=312)\end{array}$ \\
\hline Diarrhea & $5(1.6 \%)$ & $12(3.9 \%)$ & $10(3.2 \%)$ \\
\hline Headache & $2(0.6 \%)$ & $9(2.9 \%)$ & $12(3.8 \%)$ \\
\hline Abdominal pain & $6(1.9 \%)$ & $9(2.9 \%)$ & $5(1.6 \%)$ \\
\hline Dyspepsia & $2(0.6 \%)$ & $6(1.9 \%)$ & $11(3.5 \%)$ \\
\hline $\begin{array}{l}\text { Alanine aminotransferase } \\
\text { increased }\end{array}$ & $3(1.0 \%)$ & $10(3.2 \%)$ & $5(1.6 \%)$ \\
\hline Weight increased & $7(2.3 \%)$ & $8(2.6 \%)$ & $3(1.0 \%)$ \\
\hline Back pain & $4(1.3 \%)$ & $10(3.2 \%)$ & $2(0.6 \%)$ \\
\hline Respiratory infection & $8(2.6 \%)$ & $4(1.3 \%)$ & $4(1.3 \%)$ \\
\hline Hypertension & $4(1.3 \%)$ & $9(2.9 \%)$ & $2(0.6 \%)$ \\
\hline Nausea & $1(0.3 \%)$ & $5(1.6 \%)$ & $9(2.9 \%)$ \\
\hline $\begin{array}{l}\text { Aspartate } \\
\text { aminotransaminase } \\
\text { increased }\end{array}$ & 0 & $7(2.3 \%)$ & $3(1.0 \%)$ \\
\hline
\end{tabular}

hs At bedtime; om In the morning

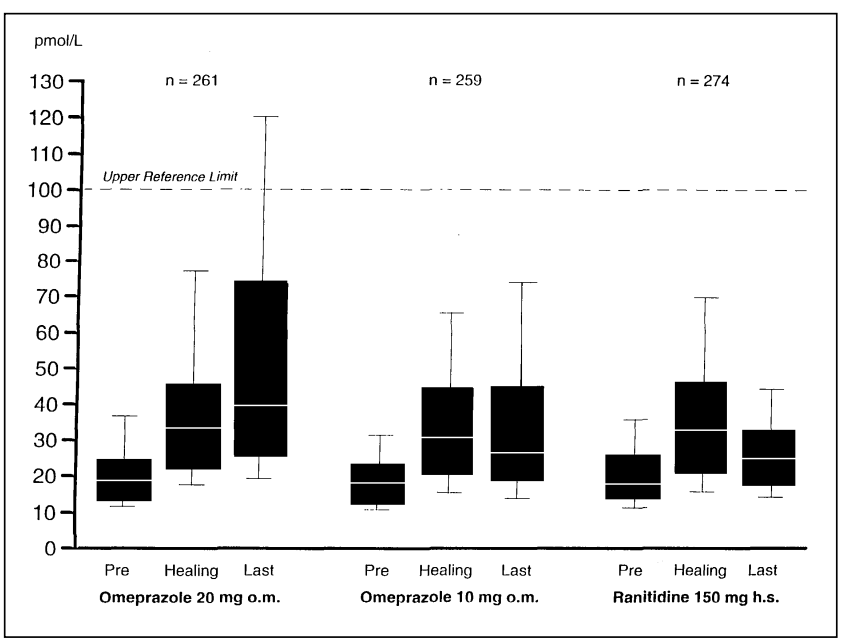

Figure 2) Box plots for the distribution of serum gastrin concentrations in the fasting state before ulcer healing treatment, at ulcer healing and at the last visit in the study in three treatment groups. The horizontal lines within each box indicate lower, median and upper quartile. The lower and upper horizontal lines outside the boxes indicate 10th and 90th percentiles, respectively. Reference interval $<100$ pmol/L. h.s. At bedtime; o.m. In the morning

was not statistically significant. Attempts to define patients at particular risk of having a relapse, by means of a Cox regression analysis of possible prognostic factors, revealed that patients requiring longer treatment courses to heal, smokers, patients with a long ulcer history and young patients seemed to have a lower chance of staying in remission. These findings agree with reports from long term treatment with cimetidine (19) or ranitidine $(20,21)$. Results from long term studies with $\mathrm{H}_{2}$ receptor antagonists have often been expressed in terms of frequency of patients with ulcer recurrences with symptoms, which also reflect the clinical practice, where pa- 
tients seeking medical care are those who have symptoms suggesting recurrence (22). For such a comparison from the present study, the rate of recurrences with symptoms in the ranitidine group of $19 \%$ is in line with earlier experience (5). However, only $7 \%$ of the patients in the omeprazole $20 \mathrm{mg}$ group experienced a recurrence with symptoms over the year. This compares with a figure of $10 \%$ for six-month recurrence in a recent smaller study comparing omeprazole $20 \mathrm{mg}$ with ranitidine $150 \mathrm{mg}(9)$.

There is concern regarding the safety of long term treatment with omeprazole (2), and safety issues such as serum gastrin measurements and histopathology have been the focus of several studies in patients with peptic ulcer disease. The safety of prolonged omeprazole treatment in the present study was assessed by evaluation of clinical and laboratory variables. Both dose regimens of omeprazole were well tolerated, and the hematological and biochemical testing confirmed the safety of such interventions. As expected, omeprazole induced a modest dose-related increase in basal serum gastrin concentrations. Most patients, however, had serum gastrin concentrations that remained within the normal reference range. This is in agreement with previous reports of longer term use of omeprazole $(6,23)$. In an open, long term trial with high dose omeprazole ( $40 \mathrm{mg}$ once a day) in patients with peptic ulcers refractory to ranitidine, the mean basal serum gastrin concentration increased above normal after four weeks, but no further increases were observed thereafter, even after up to four years of continuous observation (19).

No dysplastic or neoplastic lesions were observed in any biopsy specimen in the present study. Subatrophic or atrophic gastritis was, as expected, related to elevated serum gastrin concentrations, focal hyperplasia and high age. There was a slight increase in the severity of gastritis paralleled by an increase in the number of patients with focal hyperplasia of endocrine cells, a finding that was more prevalent among omeprazole-treated patients. The association between degree of gastritis and focal hyperplasia has been noted previously and over a longer period of time (up to four years), by Solcia et al (24), who reported slight progression of gastritis in omeprazole-treated patients. This change was associated with an increase in focal hyperplasia, which was interpreted as being a consequence of the collapse of the atrophying glands, with loss of other specialized glandular cells but with preservation of the endocrine cells (24). Progression of gastritis and hyperplasia of endocrine cells have been described in other patients followed for several years without treatment with any antisecretory drug (25). In the present study, independent of study drug (omeprazole or ranitidine), the frequency of focal hyperplasia of oxyntic mucosal endocrine cells was observed to be related to elevated basal serum gastrin concentrations.

In planning the present study, the role of $H$ pylori (26) in the relapse of duodenal ulcer disease was far from clear $(27,28)$; hence, the occurrence and the effects of treatment on this Gram-negative, microaerophilic curved bacillus were not investigated. Since then, however, a number of reports indicate a greatly reduced relapse rate after 12 months following successful eradication of $\mathrm{H}$ pylori (20-33). Attempts to eradicate the bacterium have often been associated with a high prevalence of side-effects (27), leading to low compliance in up to one-third of patients. Moreover, lack of compliance appears to be the most important factor predicting failure to eradicate the bacterium (34). Thus, although eradication of the bacterium is of primary importance when initiating treatment, it remains important to have a strategy for duodenal or gastric ulcer patients who are $H$ pylori-negative, fail to demonstrate eradication or have a tendency to become reinfected or relapse. Evaluation of these strategies should go beyond the frequency of relapse to include evaluation of the impact on dyspeptic symptoms, patient acceptability and quality of life.

\section{CONCLUSIONS}

This large controlled study provides substantial evidence that significantly more duodenal ulcer patients are maintained in remission during treatment with a standard $20 \mathrm{mg}$ dose of omeprazole daily than with $10 \mathrm{mg}$ omeprazole daily or the recommended maintenance dose of ranitidine $(150 \mathrm{mg}$ daily). Both drug interventions were well tolerated, and detailed histological and biochemical tests confirmed their safety.

ACKNOWLEDGEMENTS: This study was supported by Astra Hässle AB (a subsidiary of AB Astra, Sweden). The following investigators participated in and contributed to the study: Australia: ND Yeomans, S Kolt, I Kronborg, L Norton (Maribyrnong, Victoria), RA Smallwood, RB Sewell, RCP Watson (Heidelberg, Victoria), J St John, G Hebbard, GP Young (Parkville, Victoria), WD Reed, RA Joske, GP Jeffrey (Nedlands, Western Australia), P Kerlin, A McIntyre (Woolongabba, Queensland), AM Mackinnon, P Prichard (Bedford Park, South Australia); Canada: ABR Thomson, R Bailey (Edmonton, Alberta), AP Archambault, A Farley (Montreal, Quebec) P Paré, R Dubé, D Lévesque (Quebec, Quebec); Denmark: K Lauritsen, L Stærk Laursen (Odense), J Rask-Madsen, J Næsdal, J Kjærgaard (Bispebjerg), F Andersen, P Lund, K Nielsen, B Clausen (Sundby), H Kromann-Andersen, H Burchardt, H Luggin, K Brinck, F Baldissera (Køge), T Nilsson, P Franch, J Sandermann (Esbjerg), M Scheibel, HH Zanoni (Kjellerup), E Krag, P Matzen, T Gjørup, H Draminsky (Hvidovre), P Dan $\varnothing$, LA Christiansen, K Lindorff-Larsen (Helsingør), H Harrestrup Andersen, M Øster (Tønder), C Bekker, HJ Møller, E Højkjær-Larsen (Hjørring), C Brandsborg, JN Hansen, H Thorsøe (Silkeborg); Finland: S Kyrönpalo-Kauppinen, M Rasmussen (Tampere), T Jääskeläinen (Kemi), M Härkönen, S Jägerholm, F Rejman (Borgå); France: JP Galmiche, B Humeau (Nantes), D Goldfain, A Rotenberg (Dreux), P Zeitoun, P Renard (Reims), H Gouerou, M Robaszkiewicz (Brest), M-A Bigard, B Denis (Nancy), M Delvaux (Toulouse), J Doll, J Andrieu (Paris), P Carayon, B Folschweiller, Y Ottiyon, F Flause, JP Deschamps (Besancon), J Guillan (Evreux), J-C Grimaud, L Thervel, K Moncada, JM Brecqueville (Marseille); Germany: G Brunner, A Rahn (Hannover), M Panijel (Frankfurt), HG Rohner (Schwerte), KJ Hengels, H Jablonowski (Düsseldorf), W Tenbieg (Darmstadt); Holland: H van der Heide, JHW Bergmann (Gronigen), HPM Festen, TJM van Ditzhuijsen, EW van der Hoek (s'-Hertogenbosch); Iceland: H Gudjónsson, Á Theodórs, B Thjódleifsson, E Oddsson, TÁ Jónasson, 
O Gunnlaugsson, S Björnsson (Reykjavik); Italy: G Bianchi Porro, M Lazzaroni, S Bargiggia (Milano), L Barbara, V Stanghellini, R Corinaldesi (Bologna), A Torsoli, G Delle Fave, B Annibale, MR Cassetta (Roma); New Zealand: I Hamilton, M Lane, P Wong (Auckland), GO Barbezat, M Schlup (Dunedin); Norway: K Vetvik (Mandal), O Breder (Gjøvik), T Tønnesen, D Malm, I Toft, M Gangs øy Kristiansen, P Burhol (Troms $\varnothing$ ), H Torsvik, E Lind (Bærum), J Torjussen (Frederikstad), T Hamre (Volda), L Halvorsen, S Barstad, J Bergsåker-Aspøy (Stavanger), N Hovdenak, R Pedersen (Bergen), A Wilskow (Mosjøen); Portugal: F Costa Mira, A Ildefonso Dias Pereira, CNobre Leitão (Lisbon); Spain: M Diaz-Rubio, C Taxonera Samsõ (Madrid); Sweden: S Back, A Dahlqvist (Gävle), T Lind, M Sjövall, H Lönroth, B Jaup, A Norrby (Göteborg), K Hansson, C Rudberg, P Tracz (Västerås), M Hellblom, K Lindberg, G Edlund, C Svensson (Östersund), I Näslund, G Ågren (Örebro); United Kingdom and Ireland: JP Crowe, E Clarke (Dublin, Ireland), BD Linaker, A Allam (Warrington, United Kingdom), KFK Schiller, E Leatham (Chertsey), PM Smith, S Pugh, D Clements, S Banerjee (Penarth), JDR Rose (Mauchline, Ayrshire), JA Wilson (Kirkcaldy).

Steering committee: Gorig Brunner, Hannover, Germany; Jean Paul Galmiche, Nantes, France; Karsten Lauritsen, Odense, Denmark; Alan BR Thomson, Edmonton, Canada; Anders Walan (Astra Hässle AB), Mölndal, Sweden

Study coordinators: Kerstin Rutgersson and Elisabeth Bolling (Astra Hässle AB), Mölndal, Sweden.

Study statisticians: Sven Eriksson and Lars Frison (Astra Hässle AB), Mölndal, Sweden.

Study pathologist: Dr Niilo Havu (AB Astra), Södertälje, Sweden.

Adverse event evaluation: Karin Anckar and Anna-Karin Johansson (Astra Hässle AB), Mölndal, Sweden.

We thank the many Astra Clinical Research Associates who monitored the study, and the Data Management staff who processed the data.

\section{REFERENCES}

1. Walt RP, Gomes MD, Wood EC, Logan LH, Pounder RE. Effect of daily omeprazole on 24 hour intragastric acidity. Br Med J (Clin Res Ed) 1983;287:12-4

2. Maton PN. Omeprazole. N Engl J Med 1991;324:965-75.

3. Bianchi-Porro G, Parente F. Long term treatment of duodenal ulcer. A review of management options. Drugs 1991;41:38-51.

4. Kozarek R, Berenson M, Berkowitz J, et al. Maintenance therapy with ranitidine following healing of acute duodenal ulcer. Curr Ther Res 1985;38:341-51.

5. Gough KR, Korman MG, Bardhan KD, et al. Ranitidine and cimetidine in prevention of duodenal ulcer relapse. A doubleblind, randomised, multicentre, comparative trial. Lancet 1984;2:659-62.

6. Lauritsen K, Andersen BN, Laursen LS, et al. Omeprazole 20 mg three days a week and $10 \mathrm{mg}$ daily in prevention of duodenal ulcer relapse. Double-blind comparative trial. Gastroenterology 1991;100:663-9.

7. Bianchi-Porro G, Bolling E, Barbara L, et al. Maintenance treatment with omeprazole in the prevention of duodenal ulcer relapse. A double-blind comparative trial. Dig Dis Weekly 1990;10:A851. (Abst)

8. Pounder RE, Sharma BK, Walt RP. Twenty-four hour intragastric acidity during treatment with oral omeprazole. Scand J Gastroenterol Suppl 1986;118:108-17.

9. Diaz de Rojas F, Berenguer J, Rodrigo L, et al. Omeprazole and ranitidine in long-term treatment of duodenal ulcer. Dig Dis Sci 1998;43:1964-9.

10. Rauws EAJ. Reasons for failure of Helicobacter pylori treatment. Eur J Gastroenterol Hepatol 1993;6:105-13.

11. Lauritsen K, Rutgersson K, Bolling E, et al. Omeprazole 20 or $40 \mathrm{mg}$ daily for healing of duodenal ulcer? A double-blind comparative study. Eur J Gastroenterol Hepatol 1992;4:995-1000.

12. Solcia E, Bordi C, Creutzfeldt W, et al. Histopathological classification of nonantral gastric endocrine growth in man. Digestion 1988;41:185-200.

13. Rehfeld JF, Stadil F, Rubin B. Production and evaluation of antibodies for the radioimmunoassay of gastrin. Scand J Clin Lab Invest 1972;30:221-32.

14. Fleiss JL. Statistical Methods for Rates and Proportions. New York: Wiley, 1981.

15. Pocock SJ. Clinical Trials: A Practical Approach. New York: Wiley, 1983.

16. Lauritsen K, Rask-Madsen J. Review: clinical trials in peptic ulcer disease - problems of methodology and interpretation. Aliment Pharmacol Ther 1987;1:97-123.

17. Cox DR. The Analysis of Binary Data. London: Methuen, 1970.

18. SAS Institute Inc. SAS Technical Report P-229. Cary: SAS Institute Inc, 1992.
19. Walan A, Bianchi-Porro G, Hentschel E, Bardhan KD, Delattre M. Maintenance treatment with cimetidine in peptic ulcer disease for up to 4 years. Scand J Gastroenterol 1987;22:397-405.

20. Van Deventer GM, Elashoff JD, Reedy TJ, Schneidman D, Walsh JH. A randomized study of maintenance therapy with ranitidine to prevent the recurrence of duodenal ulcer. N Engl J Med 1989;320:1113-9.

21. Yeomans ND. Maintenance therapy for duodenal ulcer with proton pump blockers. J Gastroenterol Hepatol 1995;10:110-1.

22. Thomas JM, Misiewicz G. Histamine $\mathrm{H}_{2}$-receptor antagonists in shortand long-term treatment of duodenal ulcer. Clin Gastroenterol 1984;13:501-41.

23. Brunner G, Creutzfeldt W, Harke U, Lamberts R. Therapy with omeprazole in patients with peptic ulcerations resistant to extended high-dose ranitidine treatment. Digestion 1988;39:80-90.

24. Solcia E, Fiocca R, Havu N, Dalväg A, Carlsson R. Gastric endocrine cells and gastritis in patients receiving long-term omeprazole treatment. Digestion 1992;51(Suppl 1):82-92.

25. Havu N, Maaroos HI, Sipponen P. Argyrophilic cell hyperplasia associated with chronic corpus gastritis in gastric ulcer disease. Scand J Gastroenterol Suppl 1991;186:90-4.

26. Warren JR, Marshall BJ. Unidentified curved bacilli on gastric epithelium in active chronic gastritis. Lancet 1983;1:1273.

27. Peterson WL. Helicobacter pylori and peptic ulcer disease. N Engl J Med 1991;324:1043-8.

28. Rabeneck L, Ransohoff DF. Is Helicobacter pylori a cause of duodenal ulcer? A methodologic critique of current evidence. Am J Med 1991;91:566-72.

29. Marshall BJ, Goodwin CS, Warren JR, et al. Prospective double-blind trial of duodenal ulcer relapse after eradication of Campylobacter pylori. Lancet 1988;ii:1437-42.

30. Rauws EAJ, Tytgat GNJ. Cure of duodenal ulcer associated with eradication of Helicobacter pylori. Lancet 1990;335:1233-5.

31. Bayerdörffer E, Mannes GA, Sommer A, et al. High dose omeprazole treatment combined with amoxicillin eradicates Helicobacter pylori. Eur J Gastroenterol Hepatol 1992;4:697-702.

32. Graham DY, Lew GM, Klein PD, et al. Effect of treatment of Helicobacter pylori controlled study. Ann Intern Med 1992;116:705-8.

33. Hentschel E, Brandstätter G, Dragosics B, et al. Effect of ranitidine and amoxicillin plus metronidazole on the eradication of Helicobacter pylori and the recurrence of duodenal ulcer. N Engl J Med 1993;328:308-12.

34. Graham DY, Lew GM, Malaty HM, et al. Factors influencing the eradication of Helicobacter pylori with triple therapy. Gastroenterology 1992;102:493-6. 


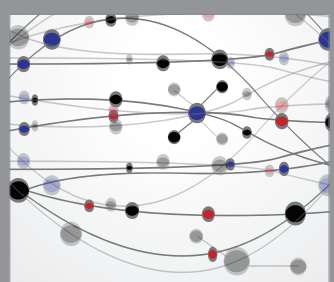

The Scientific World Journal
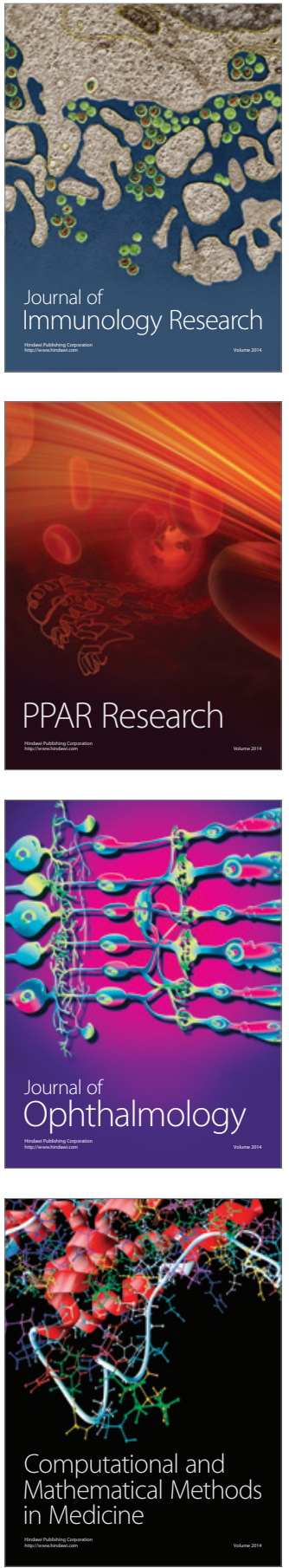

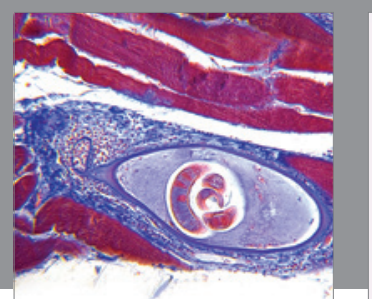

Gastroenterology Research and Practice

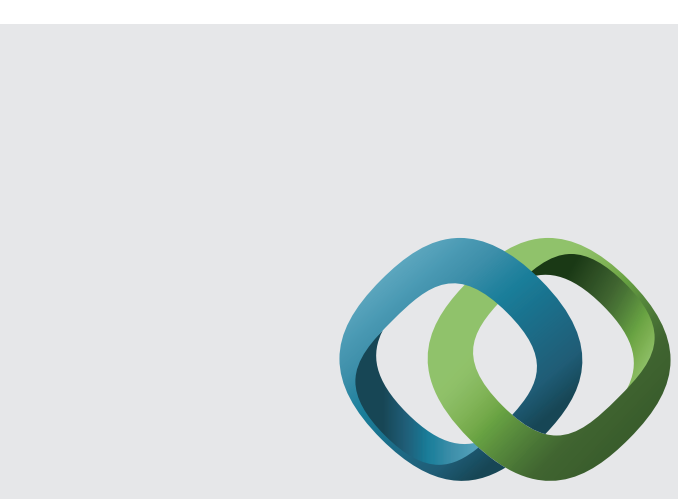

\section{Hindawi}

Submit your manuscripts at

http://www.hindawi.com
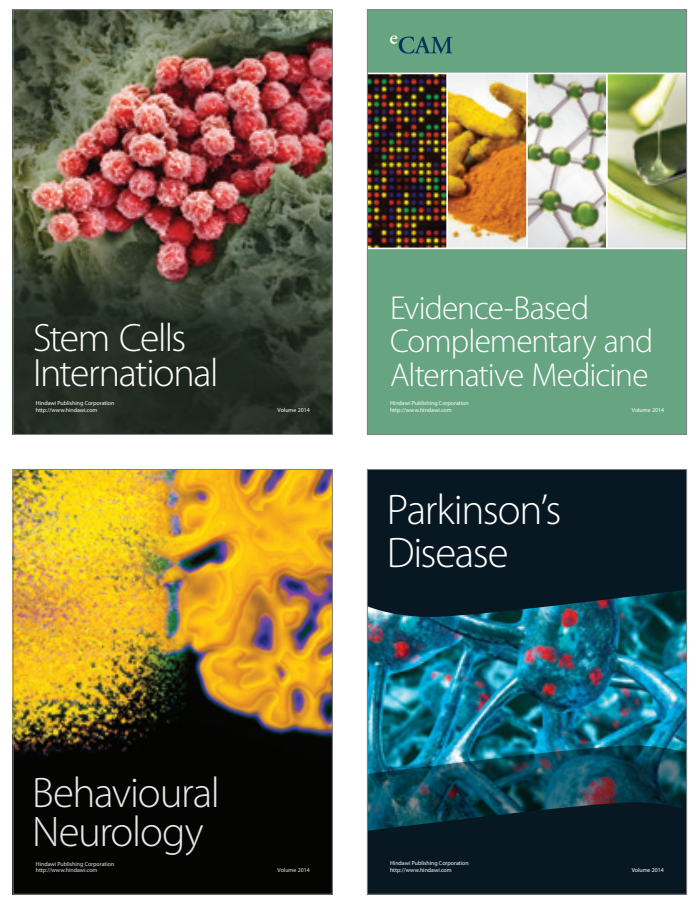
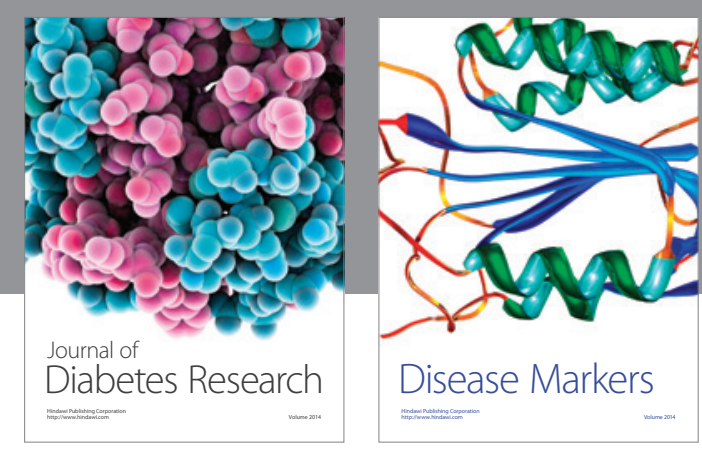

Disease Markers
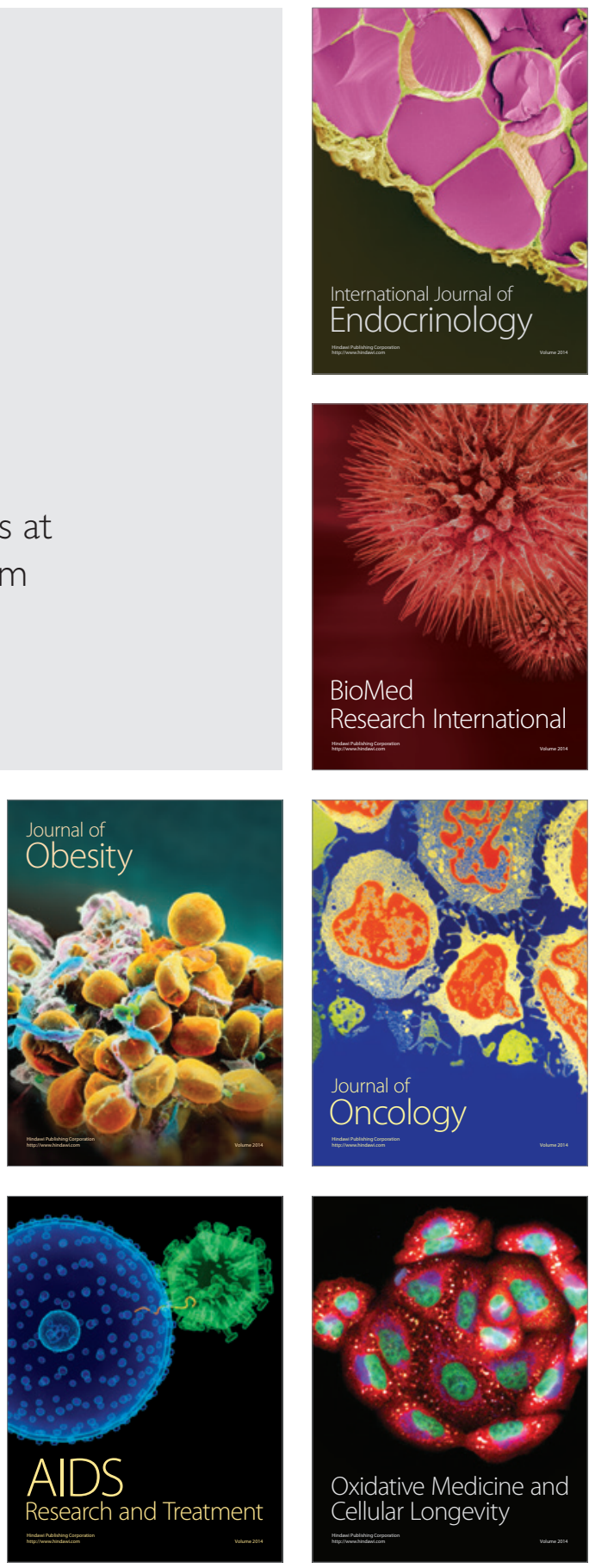